\title{
Transgenic Plants - Advantages Regarding Their Cultivation, Potentially Risks and Legislation Regarding GMO's
}

\author{
Pusta Dana Liana \\ University of Agricultural Sciences and Veterinary Medicine Cluj-Napoca \\ Romania
}

\section{Introduction}

Transgenic plants are the results of modern biotechnology. Biotechnology represents "any technological application that uses biological systems, living organisms, or derivatives thereof, to make or modify products or processes for specific use" as it was defined by the United Nations Convention on Biological Diversity. So, modern biotechnology represents the technology by which the genetic material of an organism is modified. This technique can be applied to micro-organisms, plants, animals and even to humans. This modern technology by which the genes are transferred from one organism to another is called genes technology, genetic modification, genetic engineering or bioengineering and the transferred genes are called transgenes. The receptor organism, which is transformed by the insertion of the new genes into its genome, is named transgenic organism or genetic modified organism. The donor and receptor organisms may belong to very different species which can not cross by natural means. This fact makes the differentiation of the modern biotechnology by the conventional amelioration techniques. So, the transgenic organisms can not be obtained free in nature, in natural breeding, they can be obtained just with the help of modern biotechnologies.

Genetic engineering appeared as an own scientific discipline at the beginnings of '70 and till today it has many definitions, but the most comprehensive looks to be the following: genetic engineering represents an ensemble of methods and technologies made "in vitro" with genes, chromosomes and some times with entire cells, on the purpose of "building" of some new genetic structures with premeditated hereditary properties (Popa L. and col., 1982, as cited Vlaic A., 1998).

Genetic engineering has created two new concepts such as: genetic modified organism and the term of transgenesis.

The concept of genetic modified organism represents a legislative term which groups all the organisms resulted by genetic engineering techniques, obtained by different methods of genetic recombinations.

The transgenic organism term implies the incorporation of some exterior genes, considered as useful, obtained by the recombinant DNA technology in the genome of some zygotes, resulting transgenic organisms with modified genetical properties. This gene transfer is 
called transgenesis because it presumes crossing the barriers (transgression) meaning the gene transfer between different species, especially belonging to different genus (a human gene transferred in the bacteria genome, a bacterial gene transferred into the genome of a plant or animal).

Practically the term of genetic modified organism designate every organism of which genetic patrimony was modified using the specific methods of genetic engineering.

\section{Obtaining of the genetic modified plants (transgenic plants)}

The genetic manipulation of plants has been going on since the dawn of agriculture, but until recently this has required the slow and tedious process of cross-breeding varieties. Genetic engineering promises to speed the process and broaden the scope of what can be done.

Progress is being made on several fronts to introduce new traits into plants using recombinant DNA technology. Recombinant DNA is DNA that has been created artificially. DNA from two or more sources is incorporated into a single recombinant molecule.

In order to obtain transgenic plants it is necessary to perform the following steps:

a. transfer of the gene of interest in the host cell;

b. selection of the host cells which have integrated the transgenes in their genome;

c. regeneration of some whole plants, starting from plantulas obtained by "in vitro" cultivation of the host cells;

d. cultivation of the transgenic plants in protected environments (green houses, etc.).

e. experimental cultivation of the new plants in the fields.

Each step of the operation requires some special aspects, such as:

a. transfer of the foreign gene of interest in the genome of the vegetal cell can be realized both indirectly or directly.

The indirect technique presume the using of a biologic vector, represented by some bacteria, plasmids or viruses, capable to introduce, naturally, a part of their DNA in the host cells, which provides new properties for the receptor plant. The direct method uses some techniques as the cellular microinjection of the recombinant DNA or the electro-perforation of the cellular membrane by electric shocks which produce micro-pores allowing the transgenic DNA to penetrate the new cell.

b. Selection of the host cells of the gene of interest, no matter the transfer method used. The success rate is always very low and for this reason it is necessary to associate the gene of interest with a marker gene, favorising the selection of the cells in which the transgene was integrated. The most used marker genes by the transgenic seeds producers are the ones which are codifying the resistance against an antibiotic or herbicide.

c. The regeneration and the cultivation of the transgenic plants in protected areas are made after they have been obtained in vitro. The plants obtained by cultivation in vitro, must be transferred into green houses or rooms with controlled climate. This process must be repeated for several generations, to control the expression of the new character, its hereditary transmission and the absence of the unwanted effects.

d. The experimental cultivation in field has the main aim to test the behavior of the new transgenic plant in natural conditions. Another aim is to cross the transgenic plant with 
the conventional elite type (with the best performances at the time), to obtain varieties of GMO with an increase productive efficiency. Theoretically speaking, at least, these experimental cultures should also evaluate the impact of the GMO regarding the environment and human health.

All the experimental cultures of transgenic plants are conditioned by an authorization issued by a group of official experts. The name of the transgenic plant, the nature of the experiment, the location and the dimensions of the cultivated experimental areas must be communicated to the local authorities and to the public. In average, about one decade passes between the first laboratory manipulations and the commercial cultivation of the plants, all these experiments being done with high costs.

Finally, we still mention that all the transgenic plants are protected by industrial type registered marks. All the farmers who buy GM seeds are obliged, by contract, not to keep a part of their crop for seeds and the penalties for nonobservance of the law are very high.

\section{New properties of the transgenic plants}

The obtaining and, after this, the production of the transgenic plants, with commercial aim, determined a lot of enthusiasm within the researchers. The initial enthusiasm was then followed by the opposition of the skeptics, who tried, during the time, to argue against the cultivation of transgenic plants.

The supporters of transgenic plants cultivation base their arguments on the new properties of the transgenic plants. Among these, the most important are: resistance against the herbicides (more than half of the tries), followed by the resistance against the illnesses (mostly the viral ones) and against the insects.

We will shortly describe now the properties of transgenic plants already cultivated on a large scale.

a. Resistance against the herbicides

It is manifested by the capacity of the plant to live and to develop after it was sprayed with a strong insecticide substance. This property is due to the transfer of the Bar gene which determines different enzymatic actions materialized by the transformation of the herbicide into a non toxic element. In the case of transgenic plants, the resistance against the herbicides is uni-specific, so the plant is resistant only against the herbicide for which it was created and for this reason the producer of the transgenic plant delivers also the characteristic herbicide for each transgenic plant.

b. Resistance against the insect pests

The plants having this property are permanently synthetize in their tissue an insecticide protein that determine the death of the phytophage insects. The gene codifying the resistance against the insects originates in a soil bacteria named Bacillus thuringiensis. Bacillus thuringiensis is a bacterium that is pathogenic for a number of insect pests. The lethal effect is determined by a proteic toxine which is produced. Through recombinant DNA methods, the toxin gene can be introduced directly into the genome of the plant where it is expressed and provides protection against insect pests of the plant. 
c. Resistance against illnesses

Genes that provide resistance against plant viruses have been successfully introduced into such crop plants as tobacco, tomatoes, and potatoes. By transferring the gene codifying the protein of the viral capside there were obtained plants resistant against the illnesses produced by some viruses because it blocks the propagation of the viruses in the transgenic plant.

\section{d. Resistance against freezing}

Even not on a large scale, but there were obtained GMO resistant against freezing. This type of resistance was obtained by two methods. First, the conventional cultures (especially strawberries) were treated with transgenic "antifreezing" bacteria. The second method consisted in insertion of some genes obtained from fish living in cold water, as Hippoglossus hippoglossus, a fish living in the North Sea, transferred into strawberries.

e. Improved nutritional quality

Milled rice is the staple food for a large fraction of the world's human population. Milling rice removes the husk and any beta-carotene it contained. Beta-carotene is a precursor to vitamin A, so it is not surprising that vitamin A deficiency is widespread, especially in the countries of Southeast Asia. The synthesis of beta-carotene requires a number of enzymecatalyzed steps. In January 2000, a group of European researchers reported that they had succeeded in incorporating three transgenes into rice that enabled the plants to manufacture beta-carotene in their endosperm.

\section{f. Delayed maturation}

This property was first conferred to tomatoes. In this case, there were also used two main methods:

- insertion of a gene that blocks the galacturonase, an enzyme producing the fruits softening;

- blockage of the maturating hormone synthesis; the maturation is than started by treatment with ethylene before transferring on the market.

g. Salt tolerance

A large part of the land is so laden with salt that it cannot be used to grow most important crops. However, researchers at the University of California Davis campus have created transgenic tomatoes that grow well in saline soils. The transgene was a highly-expressed sodium/proton antiport pump that sequestered excess sodium in the vacuole of leaf cells.

Due to the new properties of the transgenic plants, their supporters have valid commercial arguments to support their production, cultivation and trading.

\section{Advantages of transgenic plants presented by their producers and supporters}

The supporters of transgenic plants producing and trading say that these have a lot of advantages both for producers, for farmers, for industry, for consumers and for the environment and the human future. 
a. For the producers of the new varieties

A high efficiency in plants amelioration is obtained. The techniques of gene transfer are more precise because they allow the insulation and the propagation of the interest gene, while the classical hybridization techniques use the entire parental genomes and for this reason are needed back-crossings to emphasize the manifestation of a parental gene or to eliminate some secondary unwanted effects determined by the action of the gene in the genome. Furthermore, the number of the new characters susceptible to be conferred by gene transfer is much higher because the entire genetic information could be used despite its origin (viral, bacterial, vegetal or even human).

\section{b. For farmers}

First of all, the process of pests destroying is simplified due to the elimination of herbicides in the pre-emergent period and in the vegetation period. For the GMO only one total herbicide is necessary.

On the other hand, the production output is increasing as well as the profits of the transgenic cultures, even the obtaining cost of the GMO is rather high.

c. For industry

Due to the new properties of the transgenic plants, their processing could be also improved, as is the case of the modified starch, of low lignin content wood (in this case the paper manufacturing is less pollutant), of bio-plastics, of some human protein production (easier and in higher quantities, for therapeutic aim).

\section{d. For consumers}

Nowadays the fruits and the vegetables with delayed maturation are easier stored, with minimum losses. The maturation moment can be controlled according to the demands of the market.

In the future it is considered that transgenic plants can determine an improved human health due to the higher content of vitamins, minerals, essential aminoacids, by using the vaccine plants, the rice enriched in pro-vitamin A, etc.

e. For the environment and human future

First of all, transgenic plants imply lower pollution due to lower quantities of pesticides. Then, higher agricultural productions are obtained and people hope to eliminate the starving in the world (by extension of the areas cultivated with GMO resistant against salted soils, acid soils, lower temperatures, etc.)

\section{Risks related to the cultivation of the transgenic plants}

Despite of their advantages, it seems that the obtaining and mostly the cultivation of transgenic plants also imply some risks. The most important risks are the followings:

a. Risks related to the nowadays techniques of vegetal gene transfer

- Secondary unwanted effects. The first obtained transgenic tomato with delayed maturation was floury, with metallic taste and difficult to be transported due to its very fragile skin. Due to these reasons, the American consumers rejected it. 
- "weaknesses" in the transgene expression. For example, in USA, in 1996, the fields with transgenic cotton were destroyed in proportion of about $60 \%$ by some insects against which the plants were considered to be resistant. Similar, also in cotton, after the second treatment with herbicide it was noticed a deformation of the capsule. This could have happened because the producers have had no enough time to check the stability of the transgenic character on an enough great number of experimental fields.

b. Ambiental risks

- Limitation of the risk evaluation by experimental cultures

- Risks related to the health, materialized by some allergies and resistance to some antibiotics.

- Risks related to the biodiversity of the ecosystems by

- dissemination of the transgenic pollen to the similar spontaneous plants;

- crossings between transgenic and conventional varieties of species;

- $\quad$ apparition of some pest plants resistant against total herbicides

- $\quad$ Risks related to plants resistant to the insects attack:

- $\quad$ apparition of some pests resistant against the insecticide-protein of the Bt maize;

- intoxication of other insects by the transgenic plants

- toxicity for the enemies of the pest insects.

- Risks regarding the circuit of the insecticide toxins in soils and in the trophic chains;

- Risks determined by the cultivation techniques of the plants resistant against herbicide, insects, viruses.

- Risk of destruction of the spontaneous flora and of the plants in the neighborhood of the cultivated fields, by the total herbicides.

\section{Cultivation of the genetic modified plants worldwide}

The first commercial transgenic plants cultures started in the middle of 1990 years, in USA, where they had the fastest evolution.

Immediately after followed Argentina and Canada, where the increasing of the surfaces cultivated with transgenic plants stabilized beginning with 1999. Both countries were followed by Brazil and China.

After only 7 years from their official start, the commercial cultures of transgenic plants reached a total surface of 60 million ha at which we could add the illegal GM soy cultures in Brazil of about 1 million ha.

During the fourteen years of commercialization 1996 to 2009, the global area of biotech crops increased almost 80-fold (78.8), from 1.7 million hectares in 1996 to 134 million hectares in 2009. This rate of adoption is the highest rate of crop technology adoption for any crop technology and reflects the continuing and growing acceptance of biotech crops by farmers in both large as well as small farms and resource-poor farmers in industrial and developing countries. In the same period, the number of countries growing biotech crops quadrupled, increasing from 6 in 1996 to 12 countries in 1999, 17 in 2004, 21 countries in 2005, and 25 in 2009 (Clive J., 2010). 
Taking into account that approximately $21 \%$ of the 134 million hectares had two or three traits (planted primarily in the USA, but also increasingly in ten other countries, Argentina, Canada, the Philippines, South Africa, Australia, Mexico, Chile, Colombia, Honduras, and Costa Rica), the true global area of biotech crops in 2009 expressed as "trait hectares" was 180 million compared with 166 million "trait hectares" in 2008. Thus, the real growth rate measured in "trait hectares" between 2009 (180 million) and 2008 (166 million) was 8\% or 14 million hectares compared with the apparent growth rate of $7 \%$ or 9 million hectares when measured conservatively in hectares between 2008 (125 million hectares) and 2009 (134 million hectares). (Clive J., 2010).

The list of the higher transgenic plants which are produced includes: (http:/ / www.molecularplant-biotechnology.info/transgenic-plants/list-of-higher-plants-where-transgenic-plantshave-been-produced.htm)

Herbaceous dicotyledons, such as: Nicotiana tabacum (tobacco), N. plumbaginifolia (wild tobacco), Petunia hybrida (petunia), Lycopersicon esculentum (tomato), Solanum tuberosum (potato), Solanum melongena (eggplant), Arabidopsis thaliana, Lactuca sativa (lettuce), Apium graveolens (celery), Helianthus annuus (sunflower), Linum usitatissimum (flax), Brassica napus (oilseed rape; canola), Brassica oleracea (cauliflower), Brassica oleracea var (cabbage), Brassica rapa (syn. B. campestris), Gossypium hirsutum (cotton), Beta vulgaris (sugarbeet), Glycine max (soybean), Pisum sativum (pea), Medicago sativa (alfalfa), M. varia, Lotus corniculatum (lotus), Vigna aconitifolia, Cucumis sativus (cucumber), Cucumis mew (muskmelon), Cichorium intybus (chicory), Daucus carota (carrot), Armoracia sp. (horse radish), Glycorrhiza glabra (licorice), Digitalis' purpurea (foxglove), Ipomoea batatas (sweet potato), Ipomoea purpurea (morning glory), Fragaria sp. (strawberry), Actinidia sp. (Kiwi), Carica papaya (papaya), Vitis vinifera (grape), Vaccinium macrocarpon (cranberry), Dianthus caryophyllus (carnation), Chrysallthemum sp. (chrysanthemum), Rosa sp. (rose);

Woody dicotyledons: Populus sp. (poplar), Malus sylvestris (apple), Pyrus communis (pear), Azadirachta indica (neem), Juglans regia (walnut);

Monocotyledons: Asparagus sp. (asparagus), Daclylis glomerata (orchard grass), Secale cereale (rye), Oryza sativa (rice), Triticum aestivum (wheat), Zea mays (corn), Avena sativa (oats), Festuca arundinacea (tall fescue);

Gymmosperms (a conifer) Picea glauca (white spruce).

Analysing the list it can be noticed that nowadays genetic engineering helped the producing of a wide scale of different types of plants but just a few of them are nowadays cultivated at large scale.

The worldwide market of transgenic plants consists almost exclusively, in four species: soy, cotton, maize and rapes. The other transgenic plants (potato, papaya, tobacco, pumpkin) are cultivated only on small surfaces, non-relevant for the total cultivated ones.

The list of the EU registered GM products which are used as food or food additives comprise the following plants:

(http://ec.europa.eu/food/dyna/gm_register/index_en.cfm) 
- Soybean (MON40-3-2), MON-Ø4Ø32-6, Monsanto, genetically modified soybean that contains: cp4 epsps gene inserted to confer tolerance to the herbicide glyphosate.

- Soybean (A2704-12), ACS-GMØØ5-3, Bayer, genetically modified soybean that contains: pat gene inserted to confer tolerance to the glufosinate-ammonium herbicide.

- Soybean (MON89788), MON-89788-1, Monsanto, genetically modified soybean that contains: cp4 epsps gene inserted to confer tolerance to the herbicide glyphosate.

- Cotton (MON1445), MON-Ø1445-2, Monsanto, genetically modified cotton that contains: cp4 epsps gene inserted to confer tolerance to the herbicide glyphosate.

- Cotton (MON15985) MON-15985-7, Monsanto, genetically modified cotton that contains: cry1 Ac and cry2Ab2 genes inserted to confer insect-resistance highly selective in controlling Lepidopteran insects.

- Cotton (MON15985 x MON1445), MON-15985-7 x MON-Ø1445-2, Monsanto, Genetically modified cotton that contains: cry1Ac and cry2Ab2 genes inserted to confer insect-resistance highly selective in controlling Lepidopteran insects and cp4 epsps gene inserted to confer tolerance to the herbicide glyphosate.

- Cotton (MON531), MON-ØØ531-6, Monsanto, genetically modified cotton that contains: $\operatorname{cry} 1 \mathrm{~A}(\mathrm{c})$ gene inserted to confer insect-resistance.

- Cotton (MON531 x MON1445 ), MON-ØØ531-6 x MON-Ø1445-2, Monsanto, Genetically modified cotton that contains: $\operatorname{cry} 1 \mathrm{~A}(\mathrm{c})$ gene inserted to confer insectresistance and cp4 epsps gene inserted to confer tolerance to the herbicide glyphosate.

- Cotton (LLCotton25), ACS-GHØØ1-3, Bayer, genetically modified cotton that contains: pat gene inserted to confer tolerance to the glufosinate-ammonium herbicide.

- Cotton (GHB614), BCS-GHØØ2-5, Bayer, genetically modified cotton that expresses: 2mepsps gene inserted to confer tolerance to the glyphosate herbicides.

- Maize (Bt11), SYN-BT Ø11-1, Syngenta, genetically modified maize that contains: the crylA (b) gene inserted to confer insect-resistance and the pat gene inserted to confer tolerance to the herbicide glufosinate-ammonium.

- $\quad$ Maize (DAS59122), DAS-59122-7, Pioneer and Dow AgroSciences, genetically modified maize that contains: the cry34Ab1 and cry35Ab1 genes inserted to confer protection against certain coleopteran pests such as corn rootworm larvae (Diabrotica spp.) and pat gene inserted to confer tolerance to the glufosinate-ammonium herbicide.

- Maize (DAS1507), DAS-Ø15Ø7-1, Pioneer and Dow AgroSciences, genetically modified maize that contains: cry1F gene inserted to confer resistance to the European corn borer and certain other lepidopteran pests and pat gene inserted to confer tolerance to the herbicide glufosinate-ammonium.

- Maize (DAS1507xNK603), DAS-Ø15Ø7-1xMON-ØØ6Ø3-6, Pioneer and Dow AgroSciences, genetically modified maize that contains: cry1F gene inserted to confer protection against certain lepidopteran pests such as the European corn borer (Ostrinia nubilalis) and species belonging to the genus Sesamia, pat gene inserted to confer tolerance to the glufosinate-ammonium herbicide and cp 4epsps gene inserted to confer tolerance to the glyphosate herbicide.

- Maize (GA21), MON-ØØØ21-9, Syngenta, genetically modified maize that contains: mepsps gene inserted to confer tolerance to herbicide glyphosate.

- Maize (MON810) , MON-ØØ81Ø-6, Monsanto, genetically modified maize that contains: cryIA (b) gene inserted to confer resistance to lepidopteran pests.

- $\quad$ Maize (MON863), MON-ØØ863-5, Monsanto, genetically modified maize that contains: a trait gene cry3Bb1 inserted to confer insect- resistance and nptII gene inserted as a selection marker. 
- $\quad$ Maize (NK603), MON-ØØ6Ø3-6, Monsanto, genetically modified maize that contains: cp4 epsps gene inserted to confer tolerance to the herbicide glyphosate.

- $\quad$ Maize (NK603 x MON810), MON-ØØ6Ø3-6 x MON-ØØ81Ø-6, Monsanto, genetically modified maize that contains: cp4 epsps gene inserted to confer tolerance to glyphosate herbicides and the cry $1 \mathrm{Ab}$ gene inserted to confer protection against certain lepidopteran insect pests (Ostrinia nubilalis, Sesamia spp.).

- $\quad$ Maize (T25), ACS-ZMØØ3-2, Bayer, genetically modified maize that contains: pat gene inserted to confer tolerance to the herbicide glufosinate-ammonium.

- Maize (MON88017), MON-88Ø17-3, Monsanto, genetically modified maize that contains: modified cry3Bb1 gene inserted to confer protection to certain coleopteran pests and cp4 epsps gene inserted to confer tolerance to glyphosate herbicides.

- $\quad$ Maize (MON89034), MON-89Ø34-3, Monsanto, genetically modified maize that contains: cry1A.105 and cry2Ab2 genes inserted to confer protection to certain lepidopteran pests.

- Maize (59122xNK603), DAS-59122-7xMON-ØØ6Ø3-6, Pioneer, genetically modified maize that contains: cry34Ab1 and cry35Ab1 genes inserted to confer protection against certain coleopteran pests; pat genes inserted to confer tolerance to the glufosinateammonium herbicides and cp4 epsps genes inserted to confer tolerance to glyphosate herbicides.

- Maize (MIR604), SYN-IR6Ø4-5, Syngenta, genetically modified maize that contains: modified cry3A gene inserted to confer protection against certain coleopteran pests and pmi gene inserted as selection marker.

- $\quad$ Maize (MON863xMON810xNK603), MON-ØØ863-5xMON-ØØ81Ø-6xMON-ØØ6Ø36, Monsanto, genetically modified maize that contains: cry3Bb1 gene inserted to confer protection against certain coleopteran pests; cry1 Ab gene inserted to confer protection against certain lepidopteran insect pests; cp4 epsps gene inserted to confer tolerance to glyphosate herbicides and nptII gene inserted as a selection marker.

- Maize (MON863 x MON810 ) , MON-ØØ863-5 x MON-ØØ81Ø-6, Monsanto, genetically modified maize that contains: cry3Bb1 gene inserted to confer protection against certain coleopteran pests; cry1Ab gene inserted to confer protection against certain lepidopteran insect pests and nptII gene inserted as a selection marker.

- Maize (Bt11xGA21), SYN-BTØ11-1xMON-ØØØ21-9, Syngenta, genetically modified maize that expresses: the cry1Ab gene which confers protection against certain lepidopteran pests ; the pat gene which confers tolerance to the glufosinate-ammonium herbicides and the mepsps gene which confers tolerance to glyphosate herbicides.

- $\quad$ Maize (MON863 x NK603), MON-ØØ863-5 x MON-ØØ6Ø3-6, Monsanto, genetically modified maize that contains: cry3Bb1 gene inserted to confer protection against certain coleopteran pests; cp4 epsps gene inserted to confer tolerance to glyphosate herbicides and nptII gene inserted as a selection marker.

- $\quad$ Maize (MON88017xMON810), MON-88Ø17-3xMON-ØØ81Ø-6, Monsanto, genetically modified maize that expresses: the cry $1 \mathrm{Ab}$ gene which confers protection against certain lepidopteran pests ; the cry3Bb1 gene which provides protection to certain coleopteran pests and the cp4 epsps gene which confers tolerance to glyphosate herbicides.

- $\quad$ Maize (MON89034 xNK603), MON-89Ø34-3x MON-ØØ6Ø3-6, , Monsanto, genetically modified maize that expresses: the cry1A.105 and cry2Ab2 genes which provide protection to certain lepidopteran pests and the cp4 epsps gene which confers tolerance to glyphosate herbicides. 
- Maize (59122x1507xNK603), DAS-59122-7xDAS-Ø15Ø7xMON-ØØ6Ø3-6, Pioneer, genetically modified maize that expresses: the cry1F gene which confers protection against certain lepidopteran pests; the cry34Ab1 and cry35Ab1 genes which provide protection to certain coleopteran pests; the pat gene which confers tolerance to the glufosinate-ammonium herbicides and the cp4 epsps gene which confers tolerance to glyphosate herbicides.

- Maize (1507x59122), DAS-Ø15Ø7x DAS-59122-7, Pioneer, genetically modified maize that expresses: the cry1F gene which confers protection against certain lepidopteran pests; the cry34Ab1 and cry35Ab1 genes which provide protection to certain coleopteran pests and the pat gene which confers tolerance to the glufosinateammonium herbicides.

- Maize (MON89034 xMON88017), MON-89Ø34-3x MON-88Ø17-3, Monsanto, genetically modified maize that expresses: cry1A.105 and cry2Ab2 genes which provide protection to certain lepidopteran pests; cry3Bb1 gene which provides protection to certain coleopteran pests and cp4 epsps gene which confers tolerance to glyphosate herbicides.

- $\quad$ Oilseed rape (GT73), MON-ØØØ73-7, Monsanto, genetically modified oilseed rape that contains: cp4 epsps and goxv247 genes inserted to confer tolerance to the herbicide glyphosate.

- Oilseed rape (T45), ACS-BNØØ8-2, Bayer, genetically modified oilseed rape that contains: pat gene inserted to confer tolerance to the herbicide glufosinate-ammonium.

- $\quad$ Swede-rape (MS8, RF3, MS8xRF3), ACS-BNØØ5-8ACS-BNØØ3-6ACS-BNØØ5-8 x ACS-BN003-6, Bayer, genetically modifieds oilseed rape that contains:a bar (pat) gene inserted to confer tolerance to herbicides based on glufosinate ammonium; barnase gene inserted to leads to lack of viable pollen and male sterility and barstar gene inserted to leads to lack of viable pollen and male sterility.

- Starch potato (EH92-527-1), BPS-25271-9, BASF, genetically modified starch potato that contains: an inhibited gbss gene responsible for amylase biosynthesis. As a result, the starch product has little or no amylase and consists of amylopectin and nptII gene inserted as a selection marker.

- $\quad$ Sugar beet (H7-1), KM-ØØØ71-4, KWS SAAT and Monsanto, genetically modified sugar beet that expresses: a CP4 EPSPS protein confers tolerance to glyphosate containing herbicides.

Beside the GMO plants there also exist genetic modified microorganisms, such as: (http://ec.europa.eu/food/dyna/gm_register/index_en.cfm)

Bacterial biomass, (pCABL- Bacterial biomass ), Ajinomoto Eurolysine SAS, Bacterial protein, by-product from the production by fermentation of L-Lysine $\mathrm{HCl}$ obtained from (Brevibacterium lactofermentum) the recovered killed microorganisms. The source is the Brevibacterium lactofermentum strain SO317/pCABL, used for feed produced from GMO bacteria: " bacterial biomass".

Yeast biomass, (pMT742 or pAK729-Yeast biomass ), NOVO Nordisk A/S, NOVO Yeast Cream is a product produced from genetically modified yeast strains (Saccharomyces cerevisiae) cultivated on substrates of vegetable origin. The source is the Saccharomyces cerevisiae strain MT663/pMT742 or pAK729, used for feed materials produced from GMO yeast: "yeast biomass". 
The global impact of the genetic modified plants presents the following aspects (www.biotech-gmo.com): the additional brut margin realized by the farmers by cultivation of the genetic modified plants is of 22 billion USD, and the reduction of the pesticides quantities applied on the soil for the modified plants is about 172 million $\mathrm{kg}$, resulting an impact coefficient on the environment of $14 \%$.

Herbicide tolerance continues to be the most common transgenic trait. Herbicide tolerance is available for all of the major GM crops, including soybean, maize, rapeseed, and cotton. In 2005, the first herbicide tolerant sugar beets were approved in the US, Australia, Canada, and the Philippines. Herbicide tolerant rice and wheat already have been developed, but currently are not in use. In 2006, there was wide cultivation of herbicide tolerant alfalfa for the first time in the USA $(80,000$ hectares). In most of the cases the tolerance is to the following herbicides glyphosate (Roundup) or glufosinate-ammonium (Liberty). Such crops make up 70 percent of the 102.0 million hectares of GM crops worldwide (2006).

(http://www.gmo-compass.org/eng/agri_biotechnology/gmo_planting/145.gmo_ cultivation_trait_statistics.html)

\begin{tabular}{|c|c|c|c|c|c|c|}
\hline \multicolumn{6}{|c|}{ Global area of genetically engineered crops, 1996 to 2006: By trait (million hectares) } \\
\hline Trait & HT & IR (Bt) & IR/HT & VR/Others & Total \\
\hline 1996 & 0.6 & 1.1 & -- & $<0.1$ & $\mathbf{1 . 7}$ \\
\hline 1997 & 6.9 & 0.4 & $<0.1$ & $<0.1$ & $\mathbf{1 1 . 0}$ \\
\hline 1998 & 19.8 & 7.7 & 0.3 & $<0.1$ & $\mathbf{2 7 . 8}$ \\
\hline 1999 & 28.1 & 8.9 & 2.9 & $<0.1$ & 39.9 \\
\hline 2000 & 32.7 & 8.3 & 3.2 & $<0.1$ & $\mathbf{4 4 . 2}$ \\
\hline 2001 & 40.6 & 7.8 & 4.2 & $<0.1$ & $\mathbf{5 2 . 6}$ \\
\hline 2002 & 44.2 & 10.1 & 4.4 & $<0.1$ & $\mathbf{5 8 . 7}$ \\
\hline 2003 & 49.7 & 12.2 & 5.8 & $<0.1$ & $\mathbf{6 7 . 7}$ \\
\hline 2004 & 58.6 & 15.6 & 6.8 & $<0.1$ & $\mathbf{8 1 . 0}$ \\
\hline 2005 & 63.7 & 16.2 & 10. & $<0.1$ & $\mathbf{9 0 . 0}$ \\
\hline 2006 & 69.9 & 19.0 & 13.1 & $<0.1$ & $\mathbf{1 0 2 . 0}$ \\
\hline
\end{tabular}

\begin{tabular}{l|l}
\hline HT & Herbicide tolerance \\
\hline IR & Insect resistance (mostly Bt) \\
\hline VR & Resistance to virus diseases
\end{tabular}

Table 1. Global area of genetically engineered crops

Insect resistance is the second most common genetically modified trait. Herbicide tolerance and insect resistance $(\mathrm{Bt})$ often are introduced simultaneously to a crop in one transformation event. This is called trait stacking. The third most commonly grown transgenic crop was stacked insect resistant/herbicide tolerant maize. Combined herbicide 
and insect resistance was the fastest growing GM trait from 2004 to 2005, grown on over 6.5 million hectares in the US and Canada and comprising seven percent of the global biotech area. The recent expansion of Bt crops is mainly due to the increasing Bt maize and Bt cotton production in China, India, and Australia (Table 1 and 2).

\begin{tabular}{|c|c|c|c|c|c|c|c|}
\hline \multicolumn{7}{|c|}{ Trait-crop combinations, 1996 to 2005 (million hectares) } \\
\hline Trait & $\begin{array}{c}\text { IR } \\
\text { maize }\end{array}$ & $\begin{array}{c}\text { HT } \\
\text { maize }\end{array}$ & $\begin{array}{c}\text { IR/HT } \\
\text { maize }\end{array}$ & $\begin{array}{c}\text { IR/HT } \\
\text { cotton }\end{array}$ & $\begin{array}{c}\text { HT } \\
\text { cotton }\end{array}$ & $\begin{array}{c}\text { IR } \\
\text { cotton }\end{array}$ \\
\hline 1996 & 0.3 & 0.0 & -- & 0.0 & $<0.1$ & 0.8 \\
\hline 1997 & 3.0 & 0.2 & -- & $<0.1$ & 0.4 & 1.1 \\
\hline 1998 & 7.0 & 2.0 & -- & -- & -- & 1.0 \\
\hline 1999 & 7.5 & 1.5 & 2.1 & 0.8 & 1.6 & 1.3 \\
\hline 2000 & 6.8 & 2.1 & 1.4 & 1.7 & 2.1 & 1.5 \\
\hline 2001 & 5.9 & 2.4 & 2.5 & 1.9 & 1.8 & 2.1 \\
\hline 2002 & 7.7 & 2.5 & 2.2 & 2.2 & 2.2 & 2.4 \\
\hline 2003 & 9.1 & 3.2 & 3.2 & 2.6 & 1.5 & 3.1 \\
\hline 2004 & 11.2 & 4.3 & 3.8 & 3.0 & 1.5 & 4.5 \\
\hline 2005 & 11.3 & 3.4 & 6.5 & 3.6 & 1.3 & 4.9 \\
\hline 2006 & -- & -- & -- & -- & -- & 3.8 \\
\hline
\end{tabular}

\begin{tabular}{l|l} 
HT & Herbicide tolerance \\
\hline IR & Insect resistance (mostly Bt) \\
\hline VR & Resistance to virus diseases
\end{tabular}

Table 2. Trait -crop combinations in GMOs

\section{Legislation regarding the transgenic plants}

The purpose of a legislation system regarding the utilisation and cultivation of transgenic organisms obtained by modern biotechnology is the protection of the environment and the human health. The legislation has a preventive role and not a corrective one.

The legislation regulating the obtaining, testing, utilisation and commercialisation of the organisms obtained by modern biotechnology was elaborated in 1990 with three main objectives:

- $\quad$ to protect the human and animal health;

- $\quad$ to protect the environment;

- $\quad$ to assure the circulation of the GMO in EU;

The most important legislative act regarding GMO's in EU is the Directive 2001/18/EC and the Regulation (EC) No. 178/2002. 


\subsection{Directive 2001/18/EC}

The directive presents the legislative framework regarding the deliberate release of the genetically modified organisms (GMOs) into the environment and the placing of GMOs on the market in accordance with the precautionary principle.

(http://europa.eu/legislation_summaries/agriculture/food/128130_en.htm).

The main aim of this Directive is to make the procedure for release and placing on the market of genetically modified organisms (GMOs) and to introduce compulsory monitoring after GMOs have been placed on the market.

It also provides a common methodology to assess case-by-case the risks for the environment associated with the release of GMOs (the principles applying to environmental risk assessment are set out in Annex II to the Directive).

Public consultation and GMO labelling are made compulsory under the new Directive. Rules on the operation of these registers are laid down in Decision 2004/204/EC

The Directive invited the Commission to present a proposal for implementing the Cartagena Protocol on biosafety, which led to the adoption of Regulation (EC) No 1946/2003 on transboundary movements of genetically modified organisms.

The Directive 2001/18/EC had entry into force in 17.4.2001, the deadline for transposition in the member states of the EU was 17.10.2002 and the Official Journal in which it was published was OJ L 106 of 17.4.2001. The amending acts of Directive 2001/18/EC are represented by two regulations, Regulation (EC) No 1829/2003 and Regulation (EC) No 1830/2003, both entering into force starting with 07.11.2003, and being published into OJ L 268 of 18.10.2003.

(http://europa.eu/legislation_summaries/agriculture/food/128130_en.html).

\subsection{Regulation (EC) No. 178/2002}

Regulation (EC) No. 178/2002 of the European Parliament and of the Council of 28 January 2002 laying down the general principles and requirements of food law, establishing the European Food Safety Authority (EFSA) and laying down procedures in matters of food safety.

This Regulation provides a framework for food and feed Law within the EC. It applies to all stages of production, processing and distribution of food and feed, but does not apply to primary production for private domestic use or to the domestic preparation, handling or storage of food for private domestic consumption.

(http://www.food.gov.uk/scotland/regsscotland/regulations/scotlandfoodlawguide/sflg 200501/).

The legislation regarding the authorization for introduction of the GMO's in the environment for the experimental purpose is presented in the Directive 2001/18/EC (part B).

Important information, regulated in the part $\mathrm{C}$, are about the general aspects of GMO's labelling, free circulation and information to the public.

(http://www.biosafety.be/GB/Dir.Eur.GB/Del.Rel./2001_18/2001_18_TC.html) 


\subsection{Other legislation regarding GMO's}

Other legal instruments regarding GMO's are the followings:

- Directive 90/220/EEC on the deliberate release into the environment of genetically modified organisms entry into force on the 17-th of October 2002;

- Directive 98/81/EC amending Directive 90/219/EEC regarding the use of GMO's (http:/ / europa.eu.int/eurlex/pri/en/oj/dat/1998/1_330/1_33019981205en00130031.pdf)

- Decision 2002/623/EC establishing guidance notes supplementing Annex II to Directive 2001/18/EC.

(http://europa.eu.int/eur-

lex/pri/en/oj/dat/2002/1_200/1_20020020730en00220033.pdf)

- Decision 2002/813/EC115 establishes the format to be used by competent authorities when they provide summaries of notifications to the Commission under Article 11 of Directive 2001/18/EC.

(http://europa.eu.int/eur-

lex/pri/en/oj/dat/2002/1_280/1_28020021018en00620083.pdf)

- Decision 2003/701/EC116 establishes the format to be used by notifiers in the reporting of the results of the deliberate release to the competent authorities, as required by Article 10 of Directive 2001/18/EC

(http://europa.eu.int/eur-

lex/pri/en/oj/dat/2003/1_254/1_25420031008en00210028.pdf)

- Decision 2002/812/EC establishing pursuant to Directive 2001/18/EC the summary information format relating to the placing on the market of genetically modified organisms as or in products.

(http://europa.eu.int/eur-

lex/pri/en/oj/dat/2002/1_280/1_28020021018en00370061.pdf)

- Decision 2004/204/EC laying down detailed arrangements for the operation of the registers for recording information on genetic modifications in GMO, provided in Directive 2001/18/EC.

(http://europa.eu.int/eur-

lex/pri/en/oj/dat/2002/1_280/1_28020021018en00270036.pdf)

- Decision 2002/811/EC establishing guidance notes supplementing Annex II to Directive 2001/18/EC.

(http://europa.eu.int/eur-lex/pri/en/oj/dat/2002/1_200/1_20020020730en00220033 .pdf)

- Regulation (EC) No. 178/2002 regarding the general principles and requirements of food law.

(http://europa.eu.int/eur-

lex/pri/en/oj/dat/2002/1_031/1_03120020201en00010024.pdf)

- $\quad$ Regulation (EC) No. 1829/2003 on genetically modified food and feed;

(http:/ / europa.eu.int/eur-

lex/pri/en/oj/dat/2003/1_268/1_26820031018en00010023.pdf)

- Regulation (EC) No. 1830/2003 concerning the traceability and labelling of genetically modified organisms and traceability of food and feed products produced from genetically modified organisms.

(http://europa.eu.int/eur-

lex/pri/en/oj/dat/2003/1_268/1_26820031018en00240028.pdf) 
- Regulation (EC) No. 1946/2003 on transboundary movements of genetically modified organisms.

(http:/ / europa.eu.int/eur-

lex/pri/en/oj/dat/2003/1_287/1_28720031105en00010010.pdf)

\section{Genetical modified flowers on the market}

The research regarding the color of the flower is an ongoing process. It was noticed that in some plants the blue pigment is lacking, so the blue colored flowers cannot be obtained by classical cross-breed techniques. Genetic engineering has allowed scientists to produce carnation blue flowers even that the blue pigment is missing.

Moondust' carnation, first grown commercially in 1997, is a mini-carnation with purplemauve flowers that gets its blue color from petunia genes grafted into the DNA of the carnation. Twelve scientists at an Australian company called Florigene labored for a decade to isolate the gene responsible for blue color in petunia and then transfer it into the carnation.

To date, they have released five carnations with the "Moon" prefix, all with varying shades of mauve (Moonvista), blue (Moonshade), violet (Moonlite) or purple (Monaqua) (Fig.1).

Roses, carnations, lilies and orchids all lack a class of blue pigments called delphinidins, named after the violet-blue we see in delphinium. The gene for delphinidin production is what the Florigene scientists removed from petunia and transferred to the carnation. (http://www.arhomeandgarden.org/plantoftheweek/articles/blue_carnation.htm)

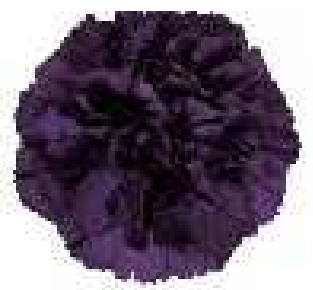

Moonvista

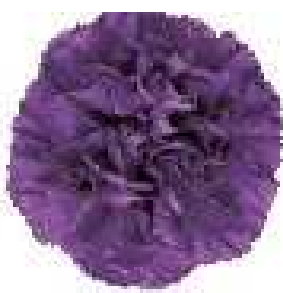

Moonshade

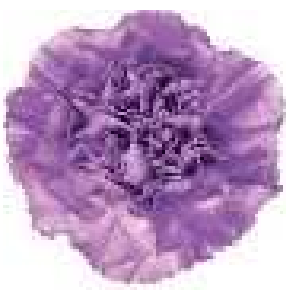

Moonlite

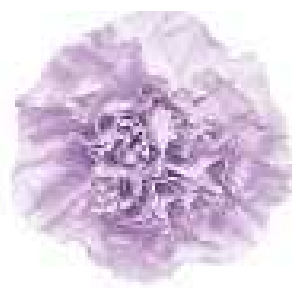

Moonaqua

Fig. 1. Florigene blue carnations

The blue carnations are cultivated in Ecuador, Columbia and Australia and commercialised in USA, Canada, Japan, EU and Australia.

Blue roses were always very desirable flowers because they symbol the mystery, the untouchable, being impossible to be produced free in nature. They were avaible on many markets, from many years, but they were not real blue roses, because they are traditionally created by dyeing white roses with blue dye.

It was in 2004 when the first blue rose was obtained by genetic engineering (Fig. 2). It was the result of the researches made by Japanese (Suntory Limited Research Centre) and Australian (Florigene) researchers and the first blue roses were officially presented to the specialists and to the market at the World Rose Convention in Osaka 2006. 


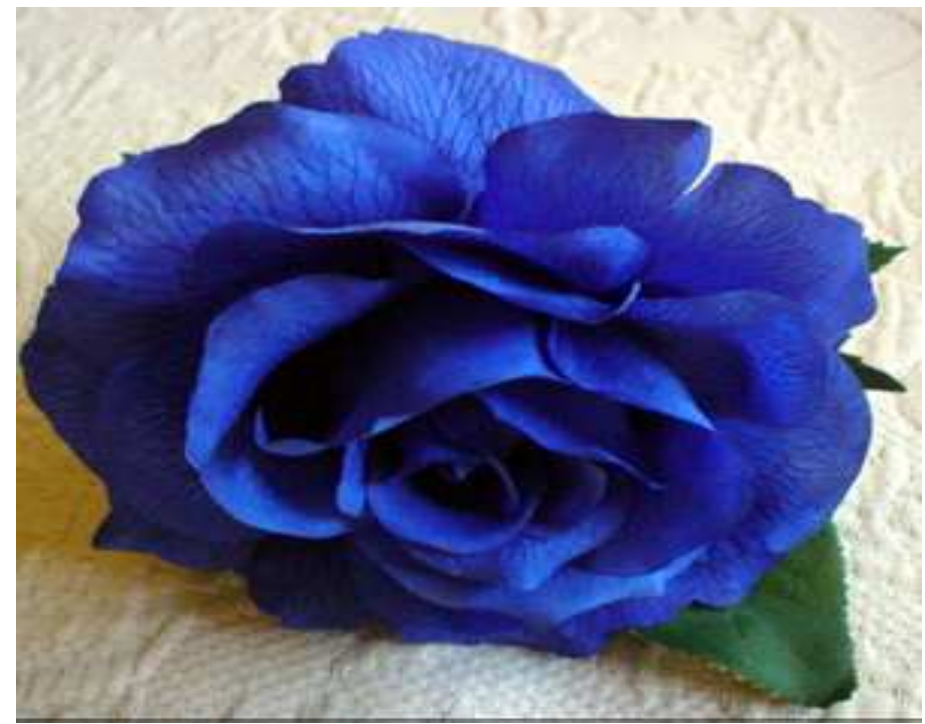

http://www.flowermeaning.info/Blue.php

Fig. 2. Blue rose presented at World Rose Convention in Osaka, 2006

The above mentioned researchers observed that the flower color is mainly determined by anthocyanins. Rosa hybrida lacks violet to blue flower varieties due to the absence of delphinidin-based anthocyanins, usually the major constituents of violet and blue flowers, because roses do not possess flavonoid $3^{\prime}, 5^{\prime}$-hydoxylase $\left(\mathrm{F}^{\prime} 5^{\prime} \mathrm{H}\right)$, a key enzyme for delphinidin biosynthesis. Other factors such as the presence of co-pigments and the vacuolar $\mathrm{pH}$ also affect flower color.

It was analyzed the flavonoid composition of hundreds of rose cultivars and measured the $\mathrm{pH}$ of their petal juice in order to select hosts of genetic transformation that would be suitable for the exclusive accumulation of delphinidin and the resulting color change toward blue. Expression of the viola $F 3^{\prime} 5^{\prime} H$ gene in some of the selected cultivars resulted in the accumulation of a high percentage of delphinidin (up to 95\%) and a novel bluish flower color.

For more exclusive and dominant accumulation of delphinidin irrespective of the hosts, the researchers down-regulated the endogenous dihydroflavonol 4-reductase (DFR) gene and over-expressed the Iris $\times$ hollandica DFR gene in addition to the viola F3'5' $H$ gene in a rose cultivar. The resultant roses exclusively accumulated delphinidin in the petals, and the flowers had blue hues not achieved by hybridization breeding. Moreover, the ability for exclusive accumulation of delphinidin was inherited by the next generations. (Yukihisa Katsumoto, 2007).

\section{Conclusions}

1. The scientific progress could be not stopped by anyone and by nothing. It is very important to use the scientific progress for the whole humanity and to be in 
concordance with the actual and the future generations' interest, without supporting the interests of only certain groups. This was the starting point of sustainability strategy which, in its essence, stipulate that the development is made for people and is realized by people.

2. The ecologic, geographic and antropic assemblies realize the landscape, with very important functions of general interest at the cultural, ecological, social level, this landscape being an important resource of the human economic activities. In this context, it should be mentioned that we don't know yet all the potential risks that the GMO could have, by long term accumulation, upon the environment.

3. The achievements of the genetic engineering have nowadays considerable benefits, but now we don't know the price we, or the future generations, will have to pay in the future for this benefits. The long term risks of the GMO are not entirely known today.

\section{References}

Apostu, S. (2006). Organisme modificate genetic folosite în alimentația şi sănătatea omului şi animalelor, Ed. Risoprint, Cluj-Napoca, ISBN 973-606-504-084-7.

Badea E. \& Otiman IP (2006). Plante modificate genetic în cultură, Ed. Mirton, Timisoara, ISBN 973-8266-36-X.

Brookes G \& P.Barfoot (2008). GM crops: global socio-economic and environmental impact 1009-2006, http://www.pgeconomics.co.uk/pdf.

Cornea C.P.; I. Vătafu \& A. Barbu (1998). Elemente de inginerie genetică, Ed. All Educațional, Bucureşti,), ISBN 973-647-282-5.

Cristea S. \& Simone Denaeyer (2004). De la biodiversitate la OGM-uri? , colecția Universitas, seria Biologie, Ed. Eikon, ISBN 973-656-036-8.

Desmond N. (2002). Genetic Engineering, Cambridge University Press.

James C. (2005). Global Status of Commercialized Biotech/GM Crops: 2009. ISAAA Brief No.39.

James C. (2008). Global Status of Commercialized Biotech/GM Crops: 2009. ISAAA Brief No.34.

James C. (2009). Global Status of Commercialized Biotech/GM Crops: 2009. ISAAA Brief No. 41. ISAAA: Ithaca, NY.

Johnson T. (1999). Gene-Changed Foods Hit Local Market, Bussiness Week, Vol. 3. No. 35.

Malschi Dana (2007). Puncte de vedere asupra prezenței organismelor genetic modificate (OGM) în agricultură, Revista Bioterra, ian-feb.-martie, 2007, p. 11-15.

Vlaic A. (1997), Inginerie genetică, Ed. Promedia Plus, Cluj-Napoca, 1997, ISBN 973-9204-71-6.

Yukihisa Katsumoto and col, 2007, Engineering of the Rose Flavonoid Biosynthetic Pathway Successfully Generated Blue-Hued Flowers Accumulating Delphinidin, Plant and Cell Physiology, Vol.48, Issue 11, pp. 1589-1600.

Consulted WEB sites:

www.biotech-gmo.com

http://www.aabiotech.org/resources

http://users.rcn.com/jkimball.ma.ultranet/BiologyPages/T/TransgenicPlants.html

http://www.gmo-compass.org/eng/agri_biotechnology/gmo_planting/

145.gmo_cultivation_trait_statistics.html 
http://www.isaaa.org/resources/publications/briefs/41/download/isaaa-brief-412009.pdf

http://www.biosafety.be/GB/Dir.Eur.GB/Del.Rel./2001_18/2001_18_TC.html

http://www.flowermeaning.info/Blue.php

http://europa.eu/legislation_summaries/agriculture/food/128130_en.html

http://www.food.gov.uk/scotland/regsscotland/regulations/scotlandfoodlawguide/sflg2 00501/

http://www.arhomeandgarden.org/plantoftheweek/articles/blue_carnation.htm

Convention on Biological Diversity, 2005, http://bch.biodiv.org/

http://europa.eu.int/eur-lex/pri/en/oj/dat/1998/1_330/1_33019981205en00130031.pdf

http://europa.eu.int/eur-lex/pri/en/oj/dat/2002/1_200/1_20020020730en00220033.pdf

http://europa.eu.int/eur-lex/pri/en/oj/dat/2002/1_280/1_28020021018en00620083.pdf http://europa.eu.int/eur-lex/pri/en/oj/dat/2003/1_254/1_25420031008en00210028.pdf http://europa.eu.int/eur-lex/pri/en/oj/dat/2002/1_280/1_28020021018en00370061.pdf http://europa.eu.int/eur-lex/pri/en/oj/dat/2002/1_280/1_28020021018en00270036.pdf http://europa.eu.int/eur-lex/pri/en/oj/dat/2002/1_200/1_20020020730en00220033.pdf http://europa.eu.int/eur-lex/pri/en/oj/dat/2002/1_031/1_03120020201en00010024.pdf http://europa.eu.int/eur-lex/pri/en/oj/dat/2003/1_268/1_26820031018en00010023.pdf http://europa.eu.int/eur-lex/pri/en/oj/dat/2003/1_268/1_26820031018en00240028.pdf) http://europa.eu.int/eur-lex/pri/en/oj/dat/2003/1_287/1_28720031105en00010010.pdf) 


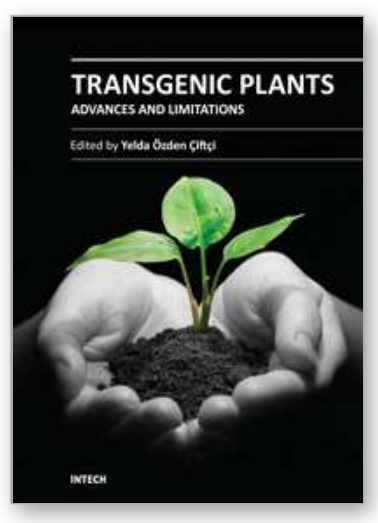

\author{
Transgenic Plants - Advances and Limitations \\ Edited by PhD. Yelda Ozden Çiftçi
}

ISBN 978-953-51-0181-9

Hard cover, 478 pages

Publisher InTech

Published online 07, March, 2012

Published in print edition March, 2012

Development of efficient transformation protocols is becoming a complementary strategy to conventional breeding techniques for the improvement of crops. Thus, Transgenic Plants - Advances and Limitations covers the recent advances carried on improvement of transformation methods together with assessment of the impact of genetically transformed crops on biosafety. Each chapter has been written by one or more experienced researchers in the field and then carefully edited to ensure throughness and consistency.

\title{
How to reference
}

In order to correctly reference this scholarly work, feel free to copy and paste the following:

Pusta Dana Liana (2012). Transgenic Plants - Advantages Regarding Their Cultivation, Potentially Risks and Legislation Regarding GMO's, Transgenic Plants - Advances and Limitations, PhD. Yelda Ozden Çiftçi (Ed.), ISBN: 978-953-51-0181-9, InTech, Available from: http://www.intechopen.com/books/transgenic-plantsadvances-and-limitations/transgenic-plants-advantages-regarding-their-cultivation-potentially-risks-andlegislation-regarding

\section{INTECH}

open science | open minds

\section{InTech Europe}

University Campus STeP Ri

Slavka Krautzeka 83/A

51000 Rijeka, Croatia

Phone: +385 (51) 770447

Fax: +385 (51) 686166

www.intechopen.com

\section{InTech China}

Unit 405, Office Block, Hotel Equatorial Shanghai

No.65, Yan An Road (West), Shanghai, 200040, China

中国上海市延安西路65号上海国际贵都大饭店办公楼 405 单元

Phone: +86-21-62489820

Fax: +86-21-62489821 
(C) 2012 The Author(s). Licensee IntechOpen. This is an open access article distributed under the terms of the Creative Commons Attribution 3.0 License, which permits unrestricted use, distribution, and reproduction in any medium, provided the original work is properly cited. 